\title{
Pacaran or Ta'aruf? \\ Contesting Two Cultural Trends of Mate Selection in Indonesia
}

\author{
Sidiq Hari Madya \\ Stockholm University
}

\begin{abstract}
In Indonesia, marriage still serves the only legal institution of family formation. However, at least since 1950s, the pattern of mate selection to expectedly end up in marriage has undergone a silent transformation from the traditional arranged to self-choice. Following the transition, two major cultural trends termed: pacaran and ta'aruf rise as popular ways of young Indonesian muslims finding their life partner.This study would examine how the changing pattern of mate selection took place in Indonesia and how, under an influence of Giddens' modernization theory, increasing cultural trends of mate selection were elaborated. Ethnographic evidences provided by previous research was presented. Current trends of mate selection were discussed. The analysis incorporated dimensions of family relations and gender differences to see how much those two aspects influenced the process of spouse choice in Indonesia. The study found that the two most-contested ideals of spouse choice in Indonesia were adopted from 'traditions' already existing in other part of the world. However, in the modern Indonesian context, to fully understand how these two emerge and currently contested cannot by simply mentioning a process of globalization without taking into account a complex social and political policy happening particularly during the last century.
\end{abstract}

\begin{abstract}
Abstrak
Di Indonesia, pernikahan masih menjadi satu-satunya insitusi legal untuk membangun keluarga. Namun, setidaknya sejak 1950-an, pola mencari calon pasangan hidup yang diharapkan sampai ke jenjang pernikahan mengalami transformasi perlahan dari tradisional ke modern. Pasca transisi tersebut, dua tren kultural mencari jodoh: pacaran dan ta'aruf menjadi begitu populer terutama dikalangan anak muda muslim Indonesia. Studi ini akan mengkaji tentang bagaimana perubahan pola mencari jodoh di Indonesia dan bagaimana, dibawah pengaruh modernisasi, meningkatnya tren kultural seperti yang disebutkan diatas, dielaborasi menggunakan konsep modernisasi oleh Giddens. Riset-riset etnografis yang pernah dilakukan sebelumnya akan ditampilkan, dua tren kultural mencari pasangan hidup yang populer saat ini didiskusikan. Analisis akan meliputi dimensi relasi keluarga dan perbedaan gender untuk melihat seberapa jauh dua aspek tersebut mepengaruhi pilihan pencarian jodoh di Indonesia. Studi ini menemukan bahwa dua tren ideal mencari jodoh yang paling dikontestasikan saat ini diadopsi dari 'tradisi' yang sudah eksis di luar Indonesia. Namun demikian dalam konteks Indonesia, untuk memahami bagaimana kedua tren ini muncul dan dikontestasikan, tidak cukup hanya dengan menyebut sebagai proses globalisasi tanpa menjelaskan kebijakan sosial dan politik yang kompleks terutama yang diterapkan pada abad sebelumnya.
\end{abstract}

Keyword: Family, gender, Giddens, Marriage, modernization, pacaran, spouse, ta'aruf

\section{Corresponding author}

Email : sidiqharim@gmail.com 


\section{Introduction}

For most young people, searching for a potential spouse might often be seen as one of the most important thing in their life. It is in that pivotal moment that young people usually think of setting idealized criteria for a future life partner which fits with their dreams on partnership, courtship, marriage and family life. The process of looking for a prospective spouse is often filled with ideal preferences and careful selection, and quite often mixed with accidental events that makes romantic love a bit more complicated and unpredicted. At the end, it is evident that spouse choice is not simply a matter of choice, rather it includes many things to consider such as social status, gender, ethnicity, faith or religion, and family background.

In Indonesian context, mate selection process is almost always expected to end up on marriage. Current data shows that the vast majority of young adults in Indonesia are married (Statistics Indonesia, 2015). Marriage still serves the only legal institution of family formation. It is often claimed that the pattern of mate selection in Indonesia have been undergone a silent transformation at least since 1950s. The transformation was explained in the way in which mate selection has experienced a transition from arranged to self-choice (Malhorta, 1991). Following that transition, a cultural phenomenon in mate selection adopting Western connotation on courtship, termed in Indonesia as pacaran, began to widespread. However, such a form of premarital relationship does not receive universal acceptance especially from Indonesian Islamic culture. An alternative way of selecting a spouse influenced by religion known as ta'aruf begins to introduce to and practiced by many young Indonesian muslims, contesting both traditional and modern-western style of selecting a spouse (Smith-Hefner, 2005).

In this paper, I would like to present the changing trends of spouse choice in Indonesia, from arranged (traditional) to self-choice (modern). To what extend can Giddens' (1992) sociological theory of modernization account for increasing trends of courtship and other type of premarital relationship in Indonesia would be the main research question of this paper. Being situated in the modern context, the increasing two cultural trends of mate selection process in Indonesia would be presented and analysed. Ethnographic evidences provided by previous research would be reviewed in much of initial part of the essay. The analysis incorporates dimensions of family relations and gender differences to see how much those two aspects have any influence in the process of spouse choice in Indonesia. The young people discussed in this paper focuses only on young Javanese muslims.

\section{Traditional arranged marriage}

In Indonesia, marriage receives a universal recognition as the only legal institution to form a family. In 1971, the number of Indonesian women aged 45-49 who never married accounted for only $1 \%$. Although in 2005 the percentage has doubled to $2 \%$, this small increase still tells the popularity of marriage for Indonesian population. Marriage is considered as a pivotal moment for the life cycle among Indonesians both for the past and current generation. Nevertheless, the process and pattern of marriage has been changing over the past fifty years. In 1960s, it is common for young woman to marry at 16 and men at 19, although this trend was more common practiced in rural area (Jones \& Gubhaju, 2008). 
Arranged marriage around the mid of $20^{\text {th }}$ century Indonesia was a custom. It can imply that family played a very important role in mate selection. Institution of family, both nuclear and extended took power over the individuals. Parental control was strong enough until the individuals, the couple ready to start their autonomy as a single unit of family. An ethnographic report documented by Geertz (1989) tells the detail about how young Indonesians in the past found a spouse. When a young man reached maturity, it's time for him to begin to seek a spouse. In the process, a woman was usually just waiting until her parent told her that a proposal came to her. Passive role of women made them have no authority to select which men they would like to marry. A woman could choose only as long as there was a man propose her. If there was no proposal during the waiting time, it was the duty of her parent to look for a potential candidate. When a suitable man was found, the girl was expected to marry him. It was rare for the girl to reject her parent's offer because she would be told that she could be unmarketable (tidak laku) in the future. The girl's acceptance was also usually viewed as an expression of her gratitude to her parents because she was raised and educated (Geertz, 1989). This reciprocal orientation characterizes intergenerational relation within family in the past generation.

As mentioned earlier, women usually played a passive role. Meanwhile men were more active. The process of searching a partner was usually limited within a neighbouring community. The family of a man commonly stayed in the same village or town with the women's. When a man has found a prospective girl, he would inquiry whether she has had a fiancée or not, if not it meant she was amenable to pick for. However, it was not always the case when she is single, the proposal would be received easily. The girl's parents would first usually inquire man's family background. This inquiry was done informally and it was relatively easy at that time to do so since they lived nearby and tied by a very strong relationship among neighbour. If the result was considered positive, a man and his parent would then pay a visit to the girl's house. This visit in a local term is called nontoni. By paying a visit, two families were able to see and discuss before making decision. The nontoni was usually held in the living room. Before the man and his family came, the girl was asked to hide herself in the back room until her parent called her to come to the living room, so that the man and his parent can see her appearance. If the first impression was positive and two parents agreed to marry prospective couple, his parent would make a formal proposal (lamaran) for the girl's parent shortly after nontoni (Geertz, 1989).

Lamaran is usually accompanied by engagement in which the girl has been given a ring as a sign that she has tied legally as her fiancée under parental or familial recognition. According to the custom, engagement period was followed by the wedding within several weeks, commonly four or five weeks. Although there was 'free time' for the bride and groom while waiting for the wedding day, the prospective couple were not allowed to meet each other. They did not have any chance to get to know deeply, personally each other until the wedding day. A few days before the wedding date, it was not appropriate most particularly for the bride, to go out of the house. The bride was expected to stay at home till the waited day arrives. This expectation has been seen as a tradition called pingitan typically lasting for few days or a week (Geertz, 1989). During pingitan, a meeting between a prospective couple was barely possible. It can be seen that mate selection in the past implied a familial rather than conjugal orientation.

Although few terms such as lamaran, nontoni, and pingitan has often been used to describe the process of traditional marriage in Indonesia, it doesn't mean that those processes were replaced when marriage trend is changing. Current marriage still survives much of traditional patterns in 
Indonesia. It is true that mate selection in the past was almost totally arranged by parents. Thus, how trust and personal relations are built for were depended on the role of their parents. The emergence of modernity, according to Giddens (1991) gives social consequences on the transformation of pattern of personal relations and intimacy. Mate selection and marriage are moving from familiar to conjugal orientation. As modern marriage increases, traditional patterns of marriage decreases. The globalizing tendency of modernity has arguably a direct correlation to the rise of conjugal orientation in mate selection process (Giddens, 1991).

It is important to take into account Indonesian social and political context, particularly related to laws on family, marriage, and education in order to understand how mate selection trends in Indonesia was changing. In 1967, Indonesia experienced a dramatic political change. The socalled 'new order' regime was started out and oriented to focus on infrastructure development and economic growth. Foreign investors were invited to forge and participate in 'National Development' project designed by the state. Funded by foreign debt, schools were built, jobs were expanded massively. A nine-years compulsory education program for boys and girls was enacted in 1984 and in 2015 expanded to 12 years (Ministry of Education and Culture, 2015). The productive ages were required to participate actively in the work force to support economic growth under national development program. The demand for completing education and participating in employment has inconsequence successfully delayed marriage ages for both sexes. New trends in partnership, mate selection, and marriage emerged.

\section{Shaping the modern trends}

In 1974, a new law regulating marriage in Indonesia was enacted, replacing previous law validated during the Dutch colonial era. This new law enactment is considered significant because it underpinned subsequent laws that regulate nuptiality such as, 'proper' age of marriage, 'proper' number of kids within a family, maximum number of wife a husband is allowed to have, etc. Under 'new order' regime, the growth of population was defined as one variable inhibiting economic growth. Therefore, the government tried to confine maximum number of children one family was supposed to have. This attempt was well known as Planned Family program using a famous 'two kids is enough' (dua anak cukup) slogan promoted widely by government-controlled media. It should be underlined that any regulation on nuptiality during 'new order' is better seen as a support for national development agenda. Although government's main programs were narrowly oriented to economic growth, the impact of national development project as a whole was considered profound, including in changing mate selection trend in the country.

Expansion of schools accompanied by compulsory education program has risen the years of schooling of Indonesian populations. In 1993, the average number of years of schooling for population aged above 15 years old was 6.16 years and had risen to 7.92 years in 2010. In the same year, the gender gap between man and women was relatively small with 8.35 years of education for men and 7.50 years for woman (Jones, 2016). At the university level, in 1990 the excess of males over females enrolled was 29\%. Men were dominant, but in 2016, gender composition in higher education is completely reversed. Today, the number of female enrolled as an active student exceeded over male students (Ministry of Research, Technology and Higher Education Indonesia, 2015). This demographic change significantly correlates to the rise of delayed age of marriage, 
most especially for women. In terms of work participation, males still have higher percentage than females, although a steady decrease for males and a slightly increase for female has occurred between 2007 to 2014 (Statistics Indonesia, 2015).

Tabel 1. Percentage of married women aged 10 years old or above and age of the first marriage (2006-2012)

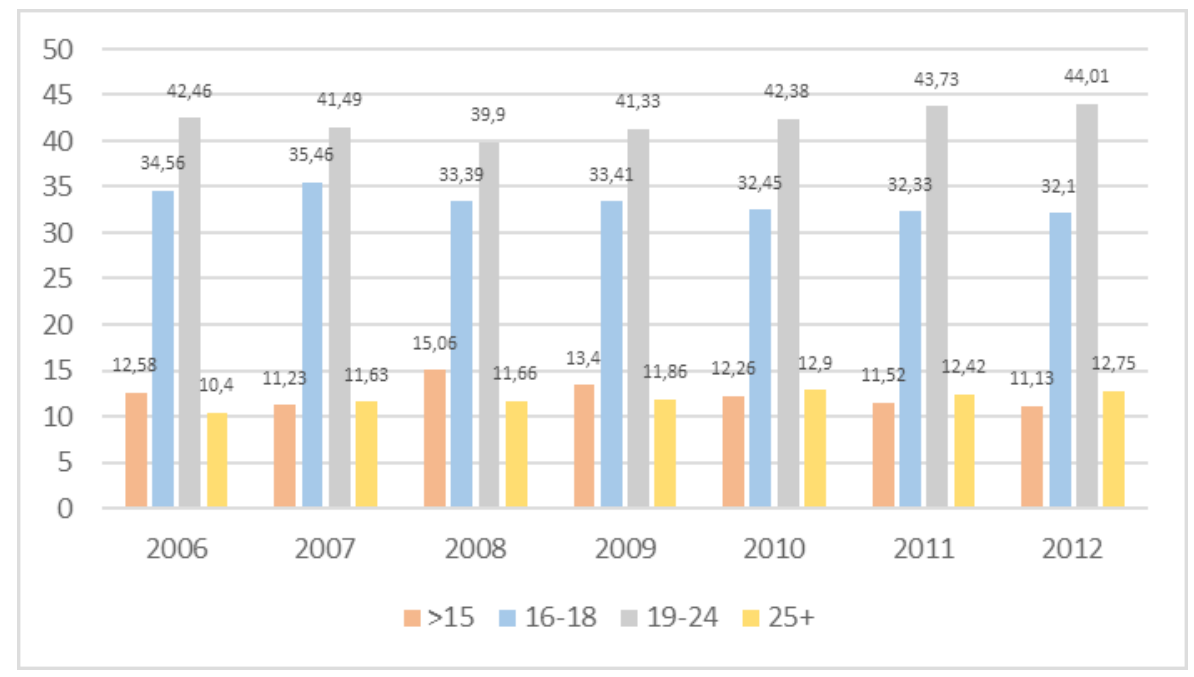

\section{Source: National Population and Family Planning Board (BKKBN) Indonesia (2012)}

As mentioned earlier, the national development project has implications to the change of marriage age more particularly for women. Entering new millennial, early marriage (before 19) has become less common for Indonesian women. As reported in the graph above, within six years, the number of women who married at the age 16-18 experienced a modest decline. Most women experienced their entry into first marriage when they were 19-24 years old. Comparing this trend with women's marriage age from the past generation, it is evident that a phenomenon of delayed marriage has been taking place, although the changing process is relatively slow. This trend does of course not exclusively happen in Indonesia which could represent developing countries, but in the developed as well. We can see this phenomenon as part of modernization process taking place in much part of the world.

Another pattern related to modern trends is the declining of 'marrying up' for women in which more women today marry men whose socioeconomic status are close to them. In the case of Indonesia, 'marrying up' also declines as women educational level increases. Educational homogamy has been rising as increasing educational attainment for women. Not only in terms of education, age gap of marriage among young people in Indonesia are becoming smaller (Utomo, 2014). The general trend that capture changing pattern of mate selection in Indonesia, as present also in many countries is a transition from arranged to self-choice relationship. It is characterized by the weakening of parental control over spouse choice (Malhorta, 1991). More time spent by young people either at school or workplace, rather than at home is a clear indication that it is no longer easy for parents to monitor and control their adult child. Intergenerational relations within the family inevitably changes. It influences the behaviour of young adults towards mate selection. The youth particularly women have more 'freedom' to look for potential spouses and initiate their love relationship. 


\section{Two cultural trends}

Delayed marriage provides longer episode for premarital relationship. Courtship has been given a way to spread. Young men and women have more chance to initiate their romantic relationship prior to marriage. For most Indonesian people, courtship is expected as a sort of entry into marriage. In Indonesia, a form of premarital self-initiated romance is termed as pacaran (often translated simply as courtship or having a girlfriend or boyfriend). Courtship in the context of Indonesia is typically seen as a form of relationship between an unmarried heterosexual couple. This form of partnership might originally be imported from the Western world. This can be seen from the existing of ambiguous terms borrowed from English that mostly expressed by those who do pacaran when they talk about such relationship. Those terms such as beb, hun, backstrit, komitmen, serius, LDR-an, troma, (baby, honey, backstreet, commitment, serious, having a long-distance relationship, trauma) (Smith-Hefner, 2005).

Typically, young people start to do pacaran when they are in a high school or above. Earlier than that is considered immature or still unstable (labil). Although pacaran grows in the modern context, in practice it is still quite strongly influenced by traditions. For example, a perception on mature age for pacaran is different between men and women. Parents tend to feel less worried to their son rather than to their daughter with respect to pacaran. This might be due to the mostperceived risk such as getting pregnant out of wedlock which is usually perceived as a shame or humiliation (aib) more for women and her family, rather than for men and his family. Therefore, women are more expected to avoid such premarital relationship in order not only to prevent the risk, but keep the good name of the family. Until getting marriage, the girls were asked to remain 'pure' and chaste (Smith-Hefner, 2005). Family still has a strong influence on decision of pacaran, and the degree of influence might differ by gender. Although it is increasingly practiced by young people, the current trend of pacaran has recently been challenged by a relatively new emerging trend in mate selection mainly driven by religious (Islamic) value in Indonesia.

Some muslims, especially those from the middle class, begin to stand against any forms of premarital relationship. Pacaran, at least for themselves, is considered inappropriate, it should be best avoided because it may easily lead to sinful act. The prohibition to do pacaran is often referred to one ayah in the Quran chapter 17 number 32: "And do not go anywhere near adultery: it is an outrage, and an evil path" (Translation by Abdel Halem). Believed as an ultimate source of truth, the Quran is used by muslims to guide their life in mind and action. However, not until the end of new order era, Indonesian muslims can express their Islamic believe more openly and freely. The religiousminded view and action have been indicated to grow within the increasing trend of public piety in Indonesia in the post-new order era. Public piety practiced by young muslims is also expressed by their attitude towards courtship and marriage (Hefner-Smith, 2005). One popular example of mate selection process practiced among young muslims that presently challenges existence of pacaran is ta'aruf, a term borrowed from Arabic (can simply be defined here as making acquaintance prior to marriage). In ta'aruf, a prospective couple might know each other through the role of a third party or the intermediary, typically a religious teacher (guru ngaji, uztad, kiai, murrobi).

If a single man or woman intend to marry, yet does not have a spouse candidate, the intermediary can help them to look for a potential spouse. In ta'aruf, a prospective couple should 
find the intermediary before stepping into engagement and marriage. Similar with period of pingitan in the past, and in contrast with courtship as a whole, ta'aruf doesn't allow the prospective couple to get together before marriage. This prohibition is often mentioned as 'belum halal' couple. The process of $t a$ 'aruf begins with exchanging of biodata resume between two candidates. In the resume, each candidate is expected to not only includes personal information but also set of criteria for his or her ideal spouse. It is important the criteria to be written down so that the intermediary can suggest whether they are suitable or not. If the resume impress both candidates, the intermediary arrange a meeting for them to discuss aimed for the candidates to know each other. The role of the intermediary is very substantial in the process of ta'aruf. A prospective couple is not permitted to meet and talk unless with the presence of intermediary. If the impression from discussion is positive, meaning that both sides agree to marry, their intention is delivered to the intermediary. From the intermediary then, the man and woman, could tell their parents that they have had a potential life partner (Hefner-Smith, 2005).

This method of selecting spouse is growing in popularity among young Indonesian muslims. Although there is no official statistical number presenting the increase, it can be indicated that public piety in mate selection is growing. The growth can also be indicated by an expansion of public discourse relating to ta'aruf stimulated by popular books, movies, television programs and other forms of popular media. In popular media, not only famous religious leaders, but many young celebrities also responsible for the popularity of ta'aruf. Increasingly a growing number of Indonesian celebrities share their love story as an example of ta'aruf through movies, books, and television programs such as soap opera and talkshows (often-mentioned famous Indonesian celebrities are Fedi Nuril and Oki Setiana Dewi). Ta'aruf situated in the broader context of mate selection can be understood as a 'modern' phenomena in the sense that parental control is relatively weak. Nevertheless, the role of the intermediary is so strong in enabling this process. Compared to pacaran, it should be emphasized that gender differences in ta'aruf is less explicit since attitudes of both men and women during the process of selection is mediated equally by the role of the third party.

\section{Conclusion}

Transition from arranged to self-choice marriage in Indonesia has been followed by plurality of ideal forms in mate selection. An increased number of youth participating in school and workforce has given rise to delayed marriage among young people. Prolonged period of mate selection has consequently created more opportunity and methods in terms of searching for a potential spouse. Self-choice marriage preceded by either pacaran or ta 'aruf implies that intimate relations are more oriented to fulfil individual expectation, therefore more conjugal than familial, but nevertheless it does not mean the role and influence of others outside the individuals is completely absent. In fact, in the case of Indonesia, parents play an important role in deciding who, when and maybe also how their adult child can express his or her love and sexuality through intimate relationship. This decision differs by gender, for example by less restraining a young boy than a girl as in the case of courtship.

Courtship as a form of premarital relationship expresses the effort of the individuals in projecting their intimate relations towards what Giddens (1992) said as 'pure relationship', since 
couple's intimacy in pacaran is more tied by emotional and sexual relation than by obligation and commitment as those in marriage. Pacaran, at least ideally, is better seen as western phenomenon adopted by many young Indonesian to select a life partner. The emergence of courtship indicates more successful realization of individual autonomy and freedom particularly in the area of sexuality and romantic love. In courtship, love and intimacy is to be expressed by both partners with selfdetermining and self-reflective modes without involving familial obligations characterized in marital relations. Thus, as Gidden says (1992), courtship decentred sexuality and released both partners form the need for reproduction. Separation between sex and reproduction is becoming more apparent. This is inevitably destroying a traditional conception on sexual relations given largely by biological considerations.

Traditional marriage pattern is currently difficult to find among young couple living especially in urban area. The pattern has shaped by modern trends which is in many respects different from previous trends. Pacaran and ta'aruf themselves might be problematic to claim as purely modern phenomenon. The phenomenon might have long existed in the west or other part of the world. However, being seen as a cultural trend, it cannot be denied that those two forms of mate selections are growing in modern Indonesia. In the 'Consequences of Modernity', Giddens (1991) mentions 'local transformation' as part of characteristics in globalizing modernity. If we consider courtship as a modern thing in Indonesia, the adoption from the west can be viewed as an expansion of Western ideology on how to find spouses. Mate selection in modern Indonesia, in short, is influenced by process of globalized modernity coming from other part of the world. The rise of ta 'aruf, however, can be conceived of contesting pacaran in the modern context.

Intimate relations in ta' aruf, can only be fulfilled through marriage. Individual aspirations are delivered through the role of intermediary without which engagement would not be possible. Although publicly appear in modern context, the process of mate selection through ta'aruf can be seen as a sort of effort of bringing back the role of religion in family formation. The whole practice of sexuality and intimacy in such process is guided by values taken from religion. Nevertheless, both partners have full autonomy to select a candidate since the role of intermediary is confined as merely an advisor, not allowed to intervene the process of selection. Both candidates have freedom to choose without any intervention from anyone. To understand shortly, romantic love in ta' aruf is principally regulated by values of religion, practically guarded by institution of marriage. In this sense, its emergence might be driven partly by anxiety of the decline of traditional family value (Chambers, 2012). Putting in the Indonesian context, it can also be understood that this cultural trend appears as an alternative or a response to 'pure relationship' which tend to put aside the institution of marriage.

Pacaran and ta'aruf have become two of the most-contested ideals of mate selection among Indonesian youth. Both cultural trends were adopted from 'traditions' initially existing in other part of the world. However, to understand how these two emerge in the modern Indonesian context, it is not simply by mentioning a process of globalization from the West or Arabs, since it includes a complex social and political policy happening during the last century. From examining those two cultural trends, it seems apparent that in a country experiencing a relatively new transition from traditional to self-choice arrangement like Indonesia, intimate relations and opportunity of 'pure relationship' is still strongly challenged by tradition and religion. Norms and values produced through family socialization shape and maintain the perceptions of young people about gender, sexualities, courtship, and marriage. More than a simple practical way of selecting ideal spouses, 
the increasing two cultural trends of spouse choice reflect an existence of contested meanings and values in mate selection process in Indonesia. 


\section{References}

Chambers, D. (2012) A Sociology of Family Life: Change and Diversity in Intimate Relations. Cambridge, England: Polity Press

Geertz, H. (1989) The Javanese Family: A Study of Kinship and Socialization. Illionis, USA: Waveland Press

Gidens, A. (1991) The Consequences of Modernity. Stanford, England: Stanford University Press

Giddens, A. (1992) The Transformation of Intimacy: Sexuality, Love and Eroticism in Modern Society. Cambridge, England: Polity Press

Haleem, A. (2004) The Qur'an. New York. USA: Oxford University Press (A new translation)

Jones, G. W. \& Gubhaju, B. (2008) Trends in Age at Marriage in the Provinces of Indonesia. Working Paper, Asia Research Institute National University of Singapore

Jones, G. W. \& Pratomo, D. (2016) Education in Indonesia: Trends, Differentials, and Implications for Development. In C. Z. Guilmoto \& G. W. Jones (Ed.), Contemporary Demographic

Transformations in China, India and Indonesia. (Vol., 5 Springer, pp. 195-213). Retrieved from https://link-springer-com.ezp.sub.su.se/book/10.1007\%2F978-3-319-24783-0 (accessed by 9 Aug 2017)

Malhorta, Anju (1991) Gender and Changing Generational Relations: Spouse Choice in Indonesia. Demography, 28(4), 549-570. Retrieved from http://www.jstor.org/stable/2061422 (Accessed by 27 Oct 2016)

Indonesian Ministry of Education and Culture (2015) The Twelve-years Compulsory Education Mandated in Nawacita. Retrieved from http://www.kemdikbud.go.id/main/blog/2015/07/ wajib-belajar-12-tahun-diamanatkan-nawacita-4366-4366-4366 (accessed by 9 Aug 2017)

Indonesian Ministry of Research, Technology and Higher Education Indonesia (2015) Graph of the Number of Active Students based on Gender. Retrieved from http://forlap.ristekdikti. go.id/mahasiswa/homegraphjk (accessed by 9 Aug 2017)

Indonesian National Population and Family Planning Board (2012) Percentage of Married Women Aged 10 Years Old or Above and Age of the First Marriage from 2006 to 2012. Retrieved from http:/www.bkkbn.go.id/kependudukan/DITRENDUK/Factsheet $\% 20$ Fertiltas\%20dan\%20Keluarga\%20Berencana/Factsheet\%20Nasional.pdf (accessed by 9 Aug 2017)

Smith-Hefner, Nancy J (2005) The New Muslim Romance: Changing Patterns of Courtship and Marriage among Educated Javanese Youth. Journal of Southeast Asian Studies, 36(3), 441459. Retrieved from http://www.jstor.org/stable/20072670 (Accessed by 1 Oct 2016)

Statistics Indonesia (2015) Population Indonesia by Province 1971-2010. Retrieved from https:// www.bps.go.id/linkTabelStatis/view/id/1267 (accessed by 9 Aug 2017)

Utomo, Ariane J. (2014) Marrying up? Trends in Age and Education Gaps among Married Couples in Indonesia. Journal of Family Issues, 35(12), 1683-1706. DOI:

$10.1177 / 0192513 X 14538023$ 